\title{
Basal Serum Thyroxine Level should Guide Initial Thyroxine Replacement Dose in Neonates with Congenital Hypothyroidism
}

\author{
(D) Ceren Günbey1, (D) Alev Özön², (1) E. Nazlı Gönç², (D) Ayfer Alikaşifoğlu², (D) Sevilay Karahan³, (D) Nurgün Kandemir² \\ ${ }^{1}$ Hacettepe University Faculty of Medicine, Department of Pediatric Neurology, Ankara, Turkey \\ 2 Hacettepe University Faculty of Medicine, Department of Pediatric Endocrinology, Ankara, Turkey \\ 3 Hacettepe University Faculty of Medicine, Department of Biostatistics, Ankara, Turkey
}

\section{What is already known on this topic?}

High initial doses of sodium-levothyroxine (10-15 $\mu \mathrm{g} / \mathrm{kg} / \mathrm{day}$ ) are recommended for rapid normalization of thyroid hormones and thyroid stimulating hormone, a marker of central nervous system hypothyroidism, for all infants with congenital hypothyroidism (CH).

\section{What this study adds?}

Our data suggest that standard high dose initial therapy in $\mathrm{CH}$ is not the only option. Adjusting the initial dose of thyroxine replacement to the basal serum free thyroxine level, with close follow-up in $\mathrm{CH}$ can be a valid strategy to provide target hormone levels while avoiding short-term iatrogenic hyperthyroxinemia.

\section{Abstract}

Objective: Initial high-dose sodium levothyroxine ( $\left.\mathrm{Na}-\mathrm{LT}_{4}\right)(10-15 \mu \mathrm{g} / \mathrm{kg} /$ day) replacement for primary congenital hypothyroidism $(\mathrm{CH})$ is recommended in guidelines. However, high-dose $\mathrm{Na}-\mathrm{LT}_{4}$ risks iatrogenic hyperthyroidism. The aim of this study was to investigate the normalizing effect of varying initial doses of $\mathrm{Na}-\mathrm{LT}_{4}$ on serum thyroid hormone levels.

Methods: Fifty-two patients were analyzed retrospectively. The patients were classified into mild (27/51.9\%), moderate (11/21.1\%) and severe $(14 / 26.9 \%) \mathrm{CH}$, based on initial free thyroxine $\left(\mathrm{fT}_{4}\right)$ levels. Time taken to achieve target hormone levels was compared within groups.

Results: Initial mean $\mathrm{Na}_{-} \mathrm{LT}_{4}$ doses for mild, moderate and severe disease were $6.9 \pm 3.3,9.4 \pm 2.2 \mathrm{and} 10.2 \pm 2 \mu \mathrm{g} / \mathrm{kg} / \mathrm{day}$. Serum fT levels reached the upper half of normal range $(>1.32 \mathrm{ng} / \mathrm{dL})$ in a median of 16,13 and 16 days in patients with mild, moderate and severe $\mathrm{CH}$ with the mean time from initial treatment to first control visit of $14.8 \pm 6$ days (range 1-36). There was no significant difference in terms of time to achieve target $\mathrm{fT}_{4}$ hormone levels according to disease severity $(\mathrm{p}=0.478)$. Seven $(25.9 \%)$, eight $(72.7 \%)$ and eight $\left(57.1 \%\right.$ ) patients experienced hyperthyroxinemia (serum $\mathrm{fT}_{4}>1.94 \mathrm{ng} / \mathrm{dL}$ ) in the mild, moderate, and severe $\mathrm{CH}$ groups at the first visit, respectively $(\mathrm{p}=0.016)$.

Conclusion: Not all patients diagnosed with $\mathrm{CH}$ require high-dose $\mathrm{Na}-\mathrm{LT}_{4}$. Initial dose of Na-LT ${ }_{4}$ may be selected on the basis of pretreatment thyroid hormone levels. Some patients with moderate and severe $\mathrm{CH}$, experienced iatrogenic hyperthyroxinemia even though the dose was close to the lower limit of the recommended range in guidelines. We suggest that lower initial doses may be appropriate with closer follow-up within the first week.

Keywords: Newborn screening, children, congenital hypothyroidism, Na-L thyroxine, dose

Address for Correspondence: Ceren Günbey MD, Hacettepe University Faculty of Medicine, Department of Pediatric Neurology, Ankara, Turkey

Phone: +90312305 1185 E-mail: cerengunbey06@gmail.com ORCID: orcid.org/0000-0003-2244-828X
Conflict of interest: None declared Received: 15.08 .2020 Accepted: 17.12 .2020 


\section{Introduction}

Congenital hypothyroidism $(\mathrm{CH})$ is the most common endocrinological problem in newborns with an incidence of 1:2000-1:4000 and has a rising incidence, as reported in recent studies $(1,2)$. Thyroid hormones are essential for brain development, especially prenatal neuronal differentiation, migration and proliferation, as well as postnatal myelinization. Thus a delay in diagnosis and treatment of permanent $\mathrm{CH}$ leads to irreversible brain damage and permanent neurodevelopmental defect $(3,4)$.

Studies suggest that rapid normalization of thyroid hormones after birth, in infants with severe hypothyroidism may provide better cognitive outcomes (5). Therefore, guidelines for neonatal screening for $\mathrm{CH}$ recommend initial replacement doses of sodium levothyroxine $\left(\mathrm{Na}-\mathrm{LT}_{4}\right)$ should be in the range 10-15 $\mathrm{gg} / \mathrm{kg} /$ day to normalize serum thyroid hormone levels, and thus thyroid stimulating hormone (TSH) level, rapidly in order to achieve better outcomes (6). The guidelines also recommend the first follow-up visit should take place no more than 1-2 weeks after the initiation of $\mathrm{Na}_{\mathrm{LT}} 4$ treatment. However significant developmental improvement could not be shown for mild to moderate hypothyroidism using higher doses $(7,8)$. Furthermore, recent data suggests a risk of iatrogenic hyperthyroxinemia may have a negative impact on behavior and attention in infants who are prescribed high initial doses $(9,10,11)$. In light of this recent evidence, the latest European Society for Pediatric Endocrinology consensus guideline suggested, for the first time, that the initial dose of $\mathrm{Na}-\mathrm{LT}_{4}$ may be titrated with respect to initial hormone levels and disease severity (12).

In the current study, we aimed to investigate the effect of varying initial doses of $\mathrm{Na}-\mathrm{LT}_{4}$ on serum thyroid hormone levels in neonates and infants with primary $\mathrm{CH}$.

\section{Methods}

Patients with primary neonatal $\mathrm{CH}$ diagnosed at Hacettepe University Medical Faculty, Division of Pediatric Endocrinology between January 2009 and January 2013 were included in the study. Patients, with a serum free thyroxine $\left(\mathrm{fT}_{4}\right)$ lower than $0.93 \mathrm{ng} / \mathrm{dL}$ (normal range: 0.93 $1.71 \mathrm{ng} / \mathrm{dL}$ ) and TSH higher than $10 \mathrm{mlU} / \mathrm{L}$ (normal range: 0.27-4.2 mIU/L) were considered to be primary $\mathrm{CH}$. Patients with a gestational age of $<37$ weeks, history of severe underlying illness or central hypothyroidism, as well as those in whom treatment was delayed for three months were excluded from the study.

Patients' files were analyzed retrospectively to identify the etiology of $\mathrm{CH}$ and severity of hypothyroidism, as determined by initial $\mathrm{fT}_{4}$ levels, as well as doses of $\mathrm{Na}-\mathrm{LT}_{4}$, and hormonal follow-up. Patients were grouped with respect to etiology, severity of $\mathrm{CH}$, and initial dose of thyroxine (low vs high). Etiological classification of the study group relied on imaging as well as re-evaluation of thyroid hormones at three years of age after cessation of treatment.

\section{Groups}

(i) Patients were categorized into two groups: (a) patients with normal thyroid function after therapy withdrawal at three years of age were classified as transient $\mathrm{CH}$; (b) patients with persistent hypothyroidism following cessation of therapy at three years of age were considered to have permanent $\mathrm{CH}$. Both groups were compared for the time to achieve target hormone levels from onset of treatment.

(ii) Patients were categorized into three groups according to pretreatment plasma $\mathrm{fT}_{4}$ concentrations: severe $\mathrm{CH}\left(\mathrm{fT}_{4}\right.$ $\leq 0.31 \mathrm{ng} / \mathrm{dL})$; moderate $\mathrm{CH}\left(0.31<\mathrm{fT}_{4} \leq 0.62 \mathrm{ng} / \mathrm{dL}\right)$ and mild $\mathrm{CH}\left(\mathrm{fT}_{4}>0.62<0.93 \mathrm{ng} / \mathrm{dL}\right)$. Mild, moderate and severe $\mathrm{CH}$ groups were compared for the time to reach target hormone levels from onset of treatment.

(iii) Patients were divided into two groups with respect to initial dose of $\mathrm{Na}^{-\mathrm{LT}_{4}}$. Those with an initial dose less than $10 \mu \mathrm{g} / \mathrm{kg} /$ day were defined as the low-dose group and those with an initial dose more than $10 \mu \mathrm{g} / \mathrm{kg} /$ day were defined as high-dose group. Both groups were compared for the time to achieve target hormone levels from onset of treatment.

\section{Hormone Levels}

Initial and follow-up thyroid hormone levels were extracted from medical records to analyze time to reach euthyroidism. Treatment targets were: (1) to achieve upper half of normal range for serum $\mathrm{fT}_{4}(>1.32 \mathrm{ng} / \mathrm{dL})$; and (2) serum $\mathrm{TSH}$ $<10 \mathrm{mIU} / \mathrm{L}$. In most patients, records included serum $\mathrm{fT}_{4}$ and TSH levels every 1-2 weeks for the first two months of life, then every 1-3 months until 12 months of age, and thereafter every three months; and more often in those with problems with compliance during follow-up, though due to the retrospective nature of the study the time intervals between visits were not homogeneous. Blood samples were obtained in the morning before $\mathrm{Na}-\mathrm{LT}_{4}$ administration.

Patients who experienced a serum $\mathrm{fT}_{4}$ level lower than 0.93 $\mathrm{ng} / \mathrm{dL}$ at the first visit were considered to be hypothyroid.

Dose management of $\mathrm{Na}-\mathrm{LT}_{4}$ was made on an individual basis by the primary endocrinologist. However, the general approach in our department is to adjust the initial dose to pretreatment $\mathrm{fT}_{4}$ levels. 
This was a retrospective analysis of medical records. Serum $\mathrm{fT}_{4}$ and $\mathrm{TSH}$ levels were measured by chemiluminescence method using IMMULITE 2000 System (Siemens, UK) during the studied period. Intra- and inter-assay variation coefficients for TSH were $5.3 \%$ and $<6.4 \%$ and $<7.1 \%$ and $<7.8 \%$ for $\mathrm{fT}_{4}$, respectively.

\section{latrogenic Hyperthyroxinemia}

Serum $\mathrm{fT}_{4}$ levels higher than $1.94 \mathrm{ng} / \mathrm{dL}$ in the first visit among transient/permanent $\mathrm{CH}$, mild/moderate/severe $\mathrm{CH}$, and low-dose/ high-dose initial therapy groups were analyzed.

This study was approved by Hacettepe University Medical Faculty Non-Invasive Clinical Research Ethics Committee (GO 13/406-24).

\section{Statistical Analysis}

Statistical analysis was performed using the Statistical Package for the Social Sciences, version 22.0 software (IBM Inc., Chicago, IL, USA). Numerical variables were summarized by mean \pm standard deviation or median (minimum-maximum) as appropriate. Normality of the numerical variables was assessed with the Shapiro-Wilks test. As all numerical data sets had skewed distribution, nonparametric tests including Kruskal-Wallis and MannWhitney U test were used to compare independent groups (such as $\mathrm{CH}$ groups). Differences between groups in terms of categorical variables were examined by the chi-square test or Fisher's exact test. A p value less than 0.05 was considered statistically significant.

\section{Results}

Seventy-one patients with $\mathrm{CH}$ were extracted from hospital records within the time frame. Of these, seven patients were excluded since the age at diagnosis was later than 45 days and eight patients were excluded for non-compliance leading to treatment failure to reach target serum levels. Furthermore, four patients with subclinical hypothyroidism with unknown cause (etiology was unknown at diagnosis, and serum $\mathrm{fT}_{4}$ were normal, however $\mathrm{TSH}$ levels were elevated after cessation of treatment at three years of age) were also excluded. Thus the final study group consisted of 52 children. Twenty-three (44.2\%) were girls and 29 $(55.5 \%)$ were boys. Mean age at diagnosis and treatment was $20.6 \pm 9.9$ days $(7-43)$. Consanguinity was present in $28.8 \%$ of the parents.

Twenty-three $(44.2 \%)$ patients had spot urinary iodine measurements, none of the results showed exposure to excessive iodine. Twenty-one (40.4\%) mothers had spot urinary iodine measurements, which showed iodine sufficiency in four (19\%) and deficiency in 17 (91\%). Seven (41.2\%) had mild (5-10 $\mu \mathrm{g} / \mathrm{dL})$, seven (41.2\%) moderate $(2-5 \mu \mathrm{g} / \mathrm{dL})$ and three $(17.6 \%)$ severe $(<2 \mu \mathrm{g} / \mathrm{dL})$ iodine deficiency. Babies of ten mothers with iodine deficiency (58.8\%) were in the transient $\mathrm{CH}$ group, whereas the remaining seven $(41.2 \%$ ) were in the permanent $\mathrm{CH}$ group.

Mean serum levels of $\mathrm{fT}_{4}$ and $\mathrm{TSH}$ at diagnosis were $0.75 \pm 0.48 \mathrm{ng} / \mathrm{dL}$ and $70.6 \pm 48.8 \mathrm{mIU} / \mathrm{L}$, respectively. Mean initial $\mathrm{Na}-\mathrm{LT}_{4}$ dose was $8.4 \pm 3.1 \mu \mathrm{g} / \mathrm{kg} /$ day. The mean time from initial treatment to first control visit was $14.8 \pm 6$ days $(1-36)$.

The median time for $\mathrm{fT}_{4}$ level to rise above $1.32 \mathrm{ng} / \mathrm{dL}$ was 16 (1-100) days, and the median time for TSH level to go below $10 \mathrm{mIU} / \mathrm{L}$ was 17 (1-88) days.

None of the patients experienced hypothyroidism at the first visit; 48 patients $\left(92.3 \%\right.$ ) achieved target serum $\mathrm{fT}_{4}$ levels and only four children $(7.7 \%)$ had $\mathrm{fT}_{4}$ levels in the lower half of the normal range (0.99-1.31 ng/dL). Three of these four had achieved target serum $\mathrm{fT}_{4}$ levels by the second visit (1231 days); one had initial low-dose $\mathrm{Na}^{-\mathrm{LT}_{4}}$ (7.14 $\mu \mathrm{g} / \mathrm{kg} /$ day) and the other two had initial high-dose Na-LT ${ }_{4}$ (10.53 and $12.2 \mu \mathrm{g} / \mathrm{kg} / \mathrm{day})$. The remaining one achieved target serum $\mathrm{fT}_{4}$ levels by the third visit (100 ${ }^{\text {th }}$ day), he had initial low-dose $\mathrm{Na}^{2} \mathrm{LT}_{4}$ (7.35 $\mu \mathrm{g} / \mathrm{kg} /$ day).

\section{Disease Severity}

Twenty-seven (51.9\%) patients had mild, 11 (21.1\%) moderate, and 14 (26.9\%) severe $\mathrm{CH}$. The mean initial Na$\mathrm{LT}_{4}$ dose given to mild, moderate and severe groups were $6.9 \pm 3.3,9.4 \pm 2.2$ and $10.2 \pm 2 \mu \mathrm{g} / \mathrm{kg} /$ day, respectively. The initial treatment dose of the mild group was significantly lower than that of moderate and severe groups $(p<0.001)$. High-dose initial $\mathrm{Na}^{-\mathrm{LT}_{4}}$ treatment was initiated in four (14.8\%), six (56.5\%) and eight $(57.1 \%)$ patients in the mild, moderate and severe groups, respectively $(p=0.006)$.

The median time for patients to reach target serum levels of $\mathrm{fT}_{4}(>1.32 \mathrm{ng} / \mathrm{dL})$ was 16 (3-49), 13 (7-100) and 16 (136) days for mild, moderate and severe groups, respectively $(p=0.478)$. The median time for patients to achieve target serum TSH levels ( $<10 \mathrm{mIU} / \mathrm{L})$ was 16 (5-31), 15 (8-27) and 30 (1-88) days in the mild, moderate and severe groups, respectively $(p=0.003)$.

\section{Permanent versus Transient Congenital Hypothyroidism}

Twenty-four (46.1\%) patients had permanent $\mathrm{CH}$, and 28 (53.9\%) had transient $\mathrm{CH}$. In the permanent $\mathrm{CH}$ group, 13 patients had dysgenesis and 11 had dyshormonogenesis. Of 13 patients with thyroid dysgenesis, three (23.1\%) had 
agenesis, eight (61.5\%) had ectopy, with one case $(7.7 \%)$ each of hypoplasia and hemiagenesis.

The mean initial Na-LT 4 dose was $9.8 \pm 2.8$ and $7.1 \pm 2.9$ $\mu \mathrm{g} / \mathrm{kg} /$ day in patients with permanent and transient $\mathrm{CH}$, respectively with the initial dose being significantly higher in patients with permanent $\mathrm{CH}(\mathrm{p}=0.003)$ (Table 1). Twelve patients $(50 \%)$ in the permanent, and six patients $(21.4 \%)$ in the transient $\mathrm{CH}$ group underwent high-dose initial $\mathrm{Na}-\mathrm{LT}_{4}$ therapy $(\mathrm{p}=0.031)$.

Thirteen (54.2\%), seven (29.2\%) and four patients (16.7\%) with severe, moderate and mild $\mathrm{CH}$, respectively, were in the permanent $\mathrm{CH}$ group. In contrast in the transient group there was one $(3.6 \%)$ child with severe $\mathrm{CH}$, and four $(14.3 \%)$ and $23(82.1 \%)$ children with moderate and mild $\mathrm{CH}$, respectively, based on pre-treatment $\mathrm{fT}_{4}$ concentration. While the patients with severe $\mathrm{CH}$ were mainly in the permanent group, the patients with mild $\mathrm{CH}$ were principally in the transient group $(p<0.001)$.

The median time for serum levels of $\mathrm{fT}_{4}$ to rise above 1.32 ng/dL was 15.5 (1-49) and 16 (3-100) days in patients with permanent and transient $\mathrm{CH}$, respectively $(\mathrm{p}=0.927)$. The median time for serum levels of TSH to decrease below 10 mIU/L was 18.5 (1-88) and 16 (5-31) days in patients with permanent and transient $\mathrm{CH}$, respectively $(\mathrm{p}=0.079)$. No statistically significant difference was found between the two groups.

\section{Low versus High Initial Dose of $\mathrm{Na}-\mathrm{LT}_{4}$}

The mean initial $\mathrm{Na}-\mathrm{LT}_{4}$ dose was $11.8 \pm 1.4 \mu \mathrm{g} / \mathrm{kg} /$ day for the patients in the high dose group $(n=18,34.6 \%)$ and $6.4 \pm 2.1 \mu \mathrm{g} / \mathrm{kg} /$ day for the low dose group $(\mathrm{n}=34,65.4 \%$ ) (Table 2).

The median time for $\mathrm{fT}_{4}$ level to increase above $1.32 \mathrm{ng} / \mathrm{dL}$ was 12.5 (1-49) days for patients in the high-dose, and 16 (3-100) days for patients in the low-dose group $(p=0.081)$. The median time for TSH level to decrease below $10 \mathrm{mIU} / \mathrm{L}$ was 17 (1-83) days for patients in the high-dose, and 17
(5-88) days for patients in the low-dose group $(p=0.664)$. No statistically significant difference was found between the groups.

\section{Overtreatment}

Analysis of $\mathrm{fT}_{4}$ levels revealed that 23 (44.2\%) patients experienced serum levels of $\mathrm{fT}_{4}>1.94 \mathrm{ng} / \mathrm{dL}$ at the first visit. None of them showed any signs/symptoms of hyperthyroidism.

The effect of high initial doses on $\mathrm{fT}_{4}$ at the first visit were compared. The mean time from initial treatment visit to first follow-up visit was $11.7 \pm 5.1$ and $16.4 \pm 6$ days in the high-dose, and low-dose treatment groups, respectively $(p=0.005)$. We compared high-dose, and low-dose initial treatment in terms of iatrogenic hyperthyroxinemia during the course of reaching treatment goals; 10 (55.5\%) and 13 (38.2\%) patients experienced serum levels of $\mathrm{fT}_{4}>1.94 \mathrm{ng} /$ $\mathrm{dL}$ in the high-dose and low-dose treatment groups at the first visit, respectively $(p=0.36)$.

Mild, moderate and severe $\mathrm{CH}$ groups were also compared in terms of iatrogenic hyperthyroxinemia at the first visit. The mean time from initial treatment visit to first followup visit was $14.9 \pm 7.7,13.4 \pm 5.8$ and $15.3 \pm 5.3$ days in mild, moderate, and severe $\mathrm{CH}$ groups, respectively $(p=0.33)$. Seven $(25.9 \%)$, eight $(72.7 \%)$ and eight $(57.1 \%)$ patients experienced serum levels of $\mathrm{fT}_{4}>1.94 \mathrm{ng} / \mathrm{dL}$ in mild, moderate, and severe $\mathrm{CH}$ groups at the first visit, respectively $(p=0.016)$

Finally, permanent and transient $\mathrm{CH}$ groups were compared in terms of iatrogenic hyperthyroxinemia at the first visit. The mean time from initial treatment visit to first follow-up visit was $14.5 \pm 6.6$ and $15.1 \pm 5.1$ days in permanent and transient groups, respectively $(p=0.47)$. Fifteen $(62.5 \%)$ and eight $(28.6 \%)$ patients experienced serum levels of $\mathrm{fT}_{4}$ $>1.94 \mathrm{ng} / \mathrm{dL}$ in the permanent and transient $\mathrm{CH}$ groups at the first visit, respectively $(p=0.03)$.

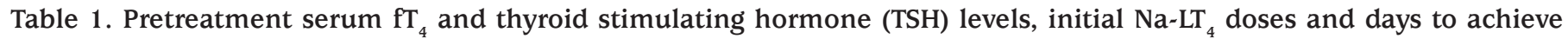
target serum $\mathrm{fT}_{4}$ and TSH levels in permanent and transient congenital hypothyroidism groups

\begin{tabular}{|c|c|c|c|c|c|c|}
\hline & & \multicolumn{3}{|c|}{ Initial levels } & \multicolumn{2}{|c|}{$\begin{array}{l}\text { Time to achieve target hormone levels } \\
\text { (days) }\end{array}$} \\
\hline & & $\mathrm{fT}_{4}^{*}$ & $\mathrm{TSH}^{*}$ & Dose* & $\mathrm{fT}_{4} * *$ & $\mathrm{TSH}^{* *}$ \\
\hline Etiology & $\mathrm{N}$ & (ng/dL) & (mIU/L) & ( $\mu g / k g /$ day) & $>1.32 \mathrm{ng} / \mathrm{dL}$ & $<10 \mathrm{mIU} / \mathrm{L}$ \\
\hline Permanent & 24 & $0.4 \pm 0.29$ & $95.1 \pm 51.7$ & $9.8 \pm 2.8$ & 15.5 & 18.5 \\
\hline Transient & 28 & $1.05 \pm 0.4$ & $49.6 \pm 35.1$ & $7.1 \pm 2.9$ & 16 & 16 \\
\hline $\mathrm{p}$ & & $<0.001$ & $<0.001$ & 0.003 & 0.927 & 0.079 \\
\hline
\end{tabular}

*Mean \pm standard deviation, **median.

$\mathrm{TSH}$ : thyroid stimulating hormone, $\mathrm{fT}_{4}$ : free thyroxine, $\mathrm{Na}-\mathrm{LT}_{4}$ : sodium levothyroxine 
Table 2. Pretreatment serum $\mathrm{fT}_{4}$ and thyroid stimulating hormone (TSH) levels, initial Na-LT ${ }_{4}$ doses and days to achieve targeted serum $\mathrm{fT}_{4}$ and $\mathrm{TSH}$ levels in high and low-dose groups

\begin{tabular}{|c|c|c|c|c|c|c|}
\hline & & \multicolumn{2}{|l|}{ Initial levels } & \multirow[b]{2}{*}{ Dose* } & \multicolumn{2}{|c|}{ Time to achieve target hormone levels (days) } \\
\hline & & $\mathrm{fT}_{4}{ }^{*}$ & $\mathrm{TSH}^{*}$ & & $\mathrm{fT}_{4} * *$ & $\mathrm{TSH}^{* *}$ \\
\hline Dose & $\mathrm{N}$ & (ng/dL) & $(\mathrm{mIU} / \mathrm{L})$ & ( $\mu \mathrm{g} / \mathrm{kg} /$ day $)$ & $>1.32 \mathrm{ng} / \mathrm{dL}$ & $<10 \mathrm{mIU} / \mathrm{L}$ \\
\hline High & 18 & $0.44 \pm 0.27$ & $102.1 \pm 54.7$ & $11.8 \pm 1.4$ & 12.5 & 17 \\
\hline Low & 34 & $0.94 \pm 0.49$ & $53.9 \pm 36.2$ & $6.4 \pm 2.1$ & 16 & 17 \\
\hline $\mathrm{p}$ & & 0.001 & $<0.001$ & $<0.001$ & 0.081 & 0.664 \\
\hline
\end{tabular}

*Mean \pm standard deviation, ** median.

TSH: thyroid stimulating hormone, $\mathrm{fT}_{4}$ : free thyroxine, $\mathrm{Na}_{-} \mathrm{LT}_{4}$ : sodium levothyroxine

\section{Discussion}

$\mathrm{CH}$ is one of the most common treatable causes of intellectual disability. Studies have shown that thyroid hormones have a crucial role in the appropriate formation of neuronal architecture as well as differentiation $(13,14)$. High initial doses of $\mathrm{Na}-\mathrm{LT}_{4}(10-15 \mu \mathrm{g} / \mathrm{kg} /$ day) are recommended for rapid normalization of thyroid hormones and TSH for all infants, irrespective of severity and cause of $\mathrm{CH}$. There are studies that have shown lower doses may also have similar success with less risk of overtreatment $(6,9,15,16)$. Supraphysiological levels of $\mathrm{fT}_{4}$ may result in premature craniosynostosis, behavioral problems, and attention impairment, and furthermore, may have a negative effect on IQ at adolescence, as one Dutch study has shown $(15,16,17,18)$. Although the importance of early detection and effective treatment of $\mathrm{CH}$ is beyond dispute, there are some controversies in standard high dose Na-LT 4 (19,20).

Soliman et al (21) reported that around one quarter of 45 patients who received high dose $\mathrm{Na}-\mathrm{LT}_{4}(15 \mu \mathrm{g} / \mathrm{kg} /$ day $)$ as initial therapy experienced hyperthyroxinemia during follow-up. Craven and Frank (9) showed high initial Na-LT 4 ( $>12.5 \mu \mathrm{g} / \mathrm{kg} /$ day) may lead to hyperthyroxinemia that required dose reduction in more than half of the patients during follow-up. They suggested a narrower range for dosing would avoid over-treatment. Furthermore, limited information is available about how a targeted dosing strategy compares to initial high dosing (10-15 $\mu \mathrm{g} / \mathrm{kg} /$ day) to achieve target serum $\mathrm{fT}_{4}$ and TSH levels. We aimed to provide some data on this issue, and we have evaluated patients diagnosed with primary $\mathrm{CH}$ and investigated the influence of different initial doses of $\mathrm{Na}-\mathrm{LT}_{4}$ on thyroid hormone levels as well as the time to achieve target levels. We also analyzed the time to achieve target hormone levels from onset of treatment in perspective of etiologies and disease severity. Furthermore, we analyzed patients who developed hyperthyroxinemia during initial hormone treatment, and its relation to initial doses, disease severity and whether $\mathrm{CH}$ was permanent or transient.
Mathai et al (22) has questioned single initial Na-LT ${ }_{4}$ dose for all $\mathrm{CH}$ patients and reviewed variable initial dose strategy in permanent $\mathrm{CH}$. In their study, $\mathrm{Na}-\mathrm{LT}_{4}$ treatment was given in 10,12 and $15 \mu \mathrm{g} / \mathrm{kg} /$ day doses for dyshormonogenesis, ectopia and athyreosis, respectively. They showed these doses succeeded in normalizing serum $\mathrm{fT}_{4}$ within 14 days. They also showed that lower doses $(9.98 \pm 3.19 \mu \mathrm{g} / \mathrm{kg} /$ day) of $\mathrm{Na}-\mathrm{LT}_{4}$ enabled target serum $\mathrm{fT}_{4}$ levels in cases with permanent $\mathrm{CH}$ within a median of 16 days. Bakker et al (23) studied $30 \mathrm{CH}$ neonates who were treated with initial daily $\mathrm{T}_{4}$ dosages ranging from 4.8 to $11.1 \mu \mathrm{g} / \mathrm{kg}$ and found no correlation between the initial dose (whether high or low) and the time for normalization of plasma $\mathrm{fT}_{4}$ levels. The mean initial $\mathrm{Na}-\mathrm{LT}_{4}$ dose was $8.4 \pm 3.1 \mu \mathrm{g} / \mathrm{kg} / \mathrm{day}$ in the current study, moreover both low $(6.4 \pm 2.1 \mu \mathrm{g} / \mathrm{kg} / \mathrm{day})$ and high $(11.8 \pm 1.4 \mu \mathrm{g} / \mathrm{kg} /$ day $)$ dose groups achieved target serum $\mathrm{fT}_{4}$ and TSH levels within similar time frames. Tuhan et al (24) studied the effect of three different initial $\mathrm{Na}-\mathrm{LT}_{4}$ doses (6-9.9 $\mu \mathrm{g} / \mathrm{kg} /$ day, $10-11.9 \mu \mathrm{g} / \mathrm{kg} /$ day and $12-17 \mu \mathrm{g} / \mathrm{kg} /$ day) on serum TSH levels in the first month, and reported no statistical difference between groups.

In the current study, varying initial doses of $\mathrm{Na}-\mathrm{LT}_{4}(6.9 \pm 3.3$; $9.4 \pm 2.2 ; 10.2 \pm 2 \mu \mathrm{g} / \mathrm{kg} /$ day) in mild, moderate, and severe $\mathrm{CH}$ groups achieved target $\mathrm{fT}_{4}$ serum concentrations within similar time-frames, suggesting titration of initial $\mathrm{Na}-\mathrm{LT}_{4}$ doses to initial hormone levels may be a valid strategy for effective treatment. We showed comparable efficacy of lower doses to achieve target serum $\mathrm{fT}_{4}$ levels in the mildly and moderately affected subgroups, against severe hypothyroidism treated with high doses. However, it took longer for the severe $\mathrm{CH}$ group to achieve target TSH serum concentrations than the mild and moderate groups (30 vs 16,15 days respectively) in our study. Persistent high serum levels of TSH in early phase of treatment has been reported. Furthermore $\mathrm{fT}_{4}$ concentration is considered more helpful in determining $\mathrm{T}_{4}$ supplementation doses in this specific time span in some studies $(23,25)$. Our results suggest impairment of hypothalamic-pituitary-thyroid axis negative feedback control may be more pronounced in the severe $\mathrm{CH}$ 
subgroup, as has previously been suggested by Hanukoglu et al (26).

Our cohort has an increased percentage of transient $\mathrm{CH}$ (53.9\%), similar to the recently published French study in which more than half of the study population had transient $\mathrm{CH}$ (27). The increased percentage of transient $\mathrm{CH}$ in these studies may be attributed to iodine deficiency in both countries $(27,28)$. Spot urinary iodine measurements of the mothers in the current study also showed that iodine deficiency is still a problem in the maternal age group. A good number of patients in both our cohort and French study presented with mild hypothyroidism at the time of diagnosis and received lower initial doses of $\mathrm{Na}-\mathrm{LT}_{4}$ in comparison to guidelines. We consider this special subgroup of patients with mild, and usually transient, hypothyroidism may be related to iodine deficiency rather than primary congenital defects of the thyroid gland or hormonogenesis, and they may need lower initial $\mathrm{Na}-\mathrm{LT}_{4}$ replacement doses. Furthermore, they may have an increased risk of overtreatment with standard high dose therapy.

Hyperthyroidism is an issue in high-dose treatment. Tuhan et al (24) studied 71 children with $\mathrm{CH}$, and showed $43.1 \%$ of patients were overtreated. Furthermore, five of them experienced clinical signs of hyperthyroidism but initial follow-up in this study was delayed. They suggested following-up thyroid functions earlier than 30 days. Mathai et al (22) monitored thyroid functions weekly and reported $28 \%$ of their patients had supraphysiological $\mathrm{fT}_{4}$ levels within the first month of treatment. Their data suggests close monitoring during the early follow-up may decrease risk of overtreatment. The mean time from initial treatment to first control visit was $14.8 \pm 6$ days in our study, and 23 (44.2\%) of the infants experienced iatrogenic hyperthyroxinemia due to overtreatment at the first visit.

Lower doses titrated to initial hormone levels were preferred in the current study, rather than the high-doses recommended in the guidelines. Yet some patients still experienced hyperthyroxinemia. Thus these results support closer follow-up, especially in patients with higher initial doses.

\section{Study Limitations}

The current study has some constraints, such as its retrospective nature and the small number of cases. In addition, neither the doses nor follow-up schedule were predetermined. Rather, they were decided by the primary endocrinologists, and time to target range of hormones depended on the follow-up schedule so that the exact timing is unknown. A limited number of babies and mothers had urinary spot urinary iodine measurements. Furthermore, anthropometric parameters and data regarding long-term neuropsychological outcome are not available.

\section{Conclusion}

Our data adds to the growing number of studies suggesting that standard high dose initial therapy needs to be reconsidered in $\mathrm{CH}$. This may be especially true for areas where mild transient $\mathrm{CH}$ is endemic due to iodine deficiency or frequent follow-up in the first weeks of treatment is not practical. We suggest that basal serum $\mathrm{fT}_{4}$ level may guide the initial dose of thyroxine replacement in neonates suspected of having $\mathrm{CH}$, and, where possible, more frequent follow-up should be employed for dose adjustment in the first weeks, in order to prevent overtreatment. Long-term studies are necessary to determine the validity of such treatment, and whether it has any impact on the neurocognitive outcomes of children with $\mathrm{CH}$.

\section{Ethics}

Ethics Committee Approval: This study was approved by Hacettepe University Medical Faculty Non-Invasive Clinical Research Ethics Committee (GO 13/406-24).

Informed Consent: Due to the retrospective nature of the study, patient consent was waived.

Peer-review: Externally peer-reviewed.

\section{Authorship Contributions}

Surgical and Medical Practices: Ceren Günbey, Alev Özön, E. Nazlı Gönç, Ayfer Alikaşifoğlu, Nurgün Kandemir, Concept: Ceren Günbey, Alev Özön, Data Collection or Processing: Ceren Günbey, Alev Özön, Analysis or Interpretation: Ceren Günbey, Alev Özön, E. Nazlı Gönç, Ayfer Alikaşifoğlu, Sevilay Karahan, Nurgün Kandemir, Literature Search: Ceren Günbey, Alev Özön, Writing: Ceren Günbey.

Financial Disclosure: The authors declared that this study received no financial support.

\section{References}

1. Rastogi MV, LaFranchi SH. Congenital hypothyroidism. Orphanet J Rare Dis 2010;5:17.

2. Hinton CF, Harris KB, Borgfeld L, Drummond-Borg M, Eaton R, Lorey F, Therrell BL, Wallace J, Pass KA. Trends in incidence rates of congenital hypothyroidism related to select demographic factors: data from the United States, California, Massachusetts, New York, and Texas. Pediatrics 2010;125(Suppl 2):37-47.

3. Prezioso G, Giannini C, Chiarelli F. Effect of thyroid hormones on neurons and neurodevelopment. Horm Res Paediatr 2018;90:73-81. Epub 2018 Aug 29 
4. Zoeller RT, Rovet J. Timing of thyroid hormone action in the developing brain: clinical observations and experimental findings. J Neuroendocrinol 2004;16:809-818.

5. Selva KA, Harper A, Downs A, Blasco PA, Lafranchi SH. Neurodevelopmental outcomes in congenital hypothyroidism: comparison of initial T4 dose and time to reach target T4 and TSH. J Pediatr 2005;147:775-780.

6. Rose SR, Brown RS, Foley T, Kaplowitz PB, Kaye CI, Sundararajan S, Varma SK. Update of newborn screening and therapy for congenital hypothyroidism. Pediatrics 2006;11 7:2290-2303.

7. Bongers-Schokking JJ, Koot HM, Wiersma D, Verkerk PH, de Muinck Keizer-Schrama SM. Influence of timing and dose of thyroid hormone replacement on development in infants with congenital hypothyroidism. J Pediatr 2000;136:292-297.

8. Simoneau-Roy J, Marti S, Deal C, Huot C, Robaey P, Van Vliet G. Cognition and behavior at school entry in children with congenital hypothyroidism treated early with high-dose levothyroxine. J Pediatr 2004;144:747-752.

9. Craven M, Frank GR. Does initial dosing of levothyroxine in infants with congenital hypothyroidism lead to frequent dose adjustments secondary to iatrogenic hyperthyroidism on follow-up? J Pediatr Endocrinol Metab 2018;31:597-600.

10. Alvarez M, Iglesias Fernandez C, Rodriguez Sanchez A, Dulin Lniguez E, Rodriguez Arnao MD. Episodes of overtreatment during the first six months in children with congenital hypothyroidism and their relationships with sustained attention and inhibitory control at school age. Horm Res Paediatr 2010;74:114-120. Epub 2010 Apr 16

11. Rovet JF, Ehrlich RM, Sorbara DL. Effect of thyroid hormone level on temperament in infants with congenital hypothyroidism detected by screening of neonates. J Pediatr 1989;114:63-68.

12. Leger J, Olivieri A, Donaldson M, Torresani T, Krude H, van Vliet G, Polak M, Butler G. European Society for Paediatric Endocrinology consensus guidelines on screening, diagnosis, and management of congenital hypothyroidism. Horm Res Paediatr 2014;81:80-103. Epub 2014 Jan 21

13. Thompson CK, Cline HT. Thyroid hormone acts locally to increase neurogenesis, neuronal differentiation, and dendritic arbor elaboration in the tadpole visual system. J Neurosci 2016;36:10356-10375.

14. Lucia FS, Pacheco-Torres J, Gonzalez-Granero S, Canals S, Obregon MJ, Garcia-Verdugo JM, Berbel P. Transient hypothyroidism during lactation arrests myelination in the anterior commissure of rats. A magnetic resonance image and electron microscope study. Front Neuroanat 2018;12:31

15. Bongers-Schokking JJ, Resing WC, de Rijke YB, de Ridder MA, de Muinck Keizer-Schrama SM. Cognitive development in congenital hypothyroidism: is overtreatment a greater threat than undertreatment? J Clin Endocrinol Metab 2013;98:4499-4506. Epub 2013 Aug 26
16. Garcia Morales L, Rodríguez Arnao MD, Rodríguez Sánchez A, Dulín Íñiguez E, Álvarez González MA. Sustained attention in school-age children with congenital hypothyroidism: Influence of episodes of overtreatment in the first three years of life. Neurologia (Engl Ed) 2020;35:226-232. (English, Spanish) Epub 2017 Nov 20

17. Penfold JL, Simpson DA. Premature craniosynostosis-a complication of thyroid replacement therapy. J Pediatr 1975;86:360-363.

18. Rovet JF, Ehrlich RM. Long-term effects of L-thyroxine therapy for congenital hypothyroidism. J Pediatr 1995;126:380-386

19. Bongers-Schokking JJ, de Muinck Keizer-Schrama SM. Influence of timing and dose of thyroid hormone replacement on mental, psychomotor, and behavioral development in children with congenital hypothyroidism. J Pediatr 2005;147:768-774.

20. Hrytsiuk I, Gilbert R, Logan S, Pindoria S, Brook CG. Starting dose of levothyroxine for the treatment of congenital hypothyroidism: a systematic review. Arch Pediatr Adolesc Med 2002;156:485-491.

21. Soliman AT, Azzam S, Elawwa A, Saleem W, Sabt A. Linear growth and neurodevelopmental outcome of children with congenital hypothyroidism detected by neonatal screening: a controlled study. Indian J Endocrinol Metab 2012;16:565-568.

22. Mathai S, Cutfield WS, Gunn AJ, Webster D, Jefferies C, Robinson E, Hofman P. A novel therapeutic paradigm to treat congenital hypothyroidism. Clin Endocrinol (Oxf) 2008;69:142-147.

23. Bakker B, Kempers MJ, De Vijlder JJ, Van Tijn DA, Wiedijk BM, Van Bruggen M, Vulsma T. Dynamics of the plasma concentrations of TSH, FT4 and T3 following thyroxine supplementation in congenital hypothyroidism. Clin Endocrinol (Oxf) 2002;57:529-537.

24. Tuhan H, Abaci A, Cicek G, Anik A, Catli G, Demir K, Bober E. Levothyroxine replacement in primary congenital hypothyroidism: the higher the initial dose the higher the rate of overtreatment. J Pediatr Endocrinol Metab 2016;29:133-138.

25. Eldar D, Kaiserman I, Sack J. Early identification of congenital hypothyroid infants with abnormalities in pituitary setpoint for T4induced TSH release. Horm Res 1993;40:194-200.

26. Hanukoglu A, Perlman K, Shamis I, Brnjac L, Rovet J, Daneman D. Relationship of etiology to treatment in congenital hypothyroidism. J Clin Endocrinol Metab 2001;86:186-191.

27. Saba C, Guilmin-Crepon S, Zenaty D, Martinerie L, Paulsen A, Simon D, Storey C, Dos Santos S, Haignere J, Mohamed D, Carel JC, Leger $\mathrm{J}$. Early determinants of thyroid function outcomes in children with congenital hypothyroidism and a normally located thyroid gland: a regional cohort study. Thyroid 2018;28:959-967. Epub 2018 Jul 30

28. Yordam N, Ozon A, Alikasifoglu A, Ozgen A, Ceren N, Zafer Y, Simsek E. Iodine deficiency in Turkey. Eur J Pediatr 1999;158:501-505. 